DOI https://doi.org/10.30525/978-9934-26-074-2-11

\title{
УЧАСТЬ ГРОМАДСЬКОСТІ В УХВАЛЕННІ ВЛАДНИХ РІШЕНЬ У ГРОМАДАХ
}

\author{
Омельчук O. I. \\ аспірант кафедри публічного управління та публічної служби \\ Національної академії державного управління \\ при Президентові Украӥни \\ м. Київ, Украӥна
}

Під час реформи децентралізації в Україні та у процесі активного становлення нових об'єднаних територіальних громад, надзвичайно актуальним питанням $є$ зміцнення їх спроможності. Децентралізацію відносять до п'ятірки найбільш динамічних українських реформ за показником сприйняття. Активна комунікація допомагає українцям зрозуміти, що відбувається в країні у сфері реформ та формує їх ставлення до змін. Протягом тривалого періоду громадяни не мали ефективних важелів впливу на управління державою, внаслідок чого сформувалися і стали нормальними моделі поведінки, при яких громадяни уникають відповідальності за свої дії або повністю чи частково перекладають відповідальність на інших. Та сучасна Україна вимагає зовсім іншої моделі поведінки, і перехід на цю модель $є$ багаторівневий. Депутатам місцевих рад, представникам інших органів місцевого самоврядування, провідним лідерам, керівникам і працівникам окрім необхідності розібратись у своїх нових обов'язках для належного їх виконання треба й залучити громадян до співробітництва через ефективні, відкриті та прозорі шляхи комунікації [3, с. 75].

Так, місцевий розвиток великою мірою залежить від результативності спільних зусиль органів місцевої влади та громадськості, спільною ціллю яких і $є$ зміцнення спроможності в усіх сферах життєдіяльності громади. А відтак, і відповідальність за місцевий розвиток покладається на обидві сторони - владу громади та ії жителів. В громадах мають з'являються та діють якісні моделі взаємодії місцевої влади і громадян, побудовані на демократичних та правових засадах. Для цього органам місцевого самоврядування необхідно створити сприятливі умови для участі населення у вирішенні питань місцевого значення. Насамперед ідеться про встановлення чітких і зрозумілих «правил гри» як для органів влади, так і для жителів. Установити ці правила можна за допомогою демократичних процедур участі населення в процесі ухвалення рішень, використання яких покликане перетворити безсистемну та неефективну 
взаємодію мешканців і органів влади на конструктивний та сталий діалог. Аналіз практик залучення мешканців до процесу вироблення та ухвалення рішень в громадах показує, що чимало громад намагаються розвивати демократію участі за допомогою різних інструментів. При цьому процес взаємодії розпочинається та проходить по-різному. В одних громадах ініціатива щодо співробітництва надходить від місцевої ради; в інших, навпаки, активні мешканці самі ініціюють діалог. С також приклади, коли співпраця влади та мешканців розвивається із взаємної ініціативи обох сторін. Власне, громади обирають інструменти взаємодії: розвиток органів самоорганізації населення, громадські експертизи діяльності влади, консультації з громадськістю, громадські ради, загальні збори громадян, тощо. [2]

Відповідно, місцеві органи влади докладають максимум зусиль для впровадження цього інструменту - ухвалюють положення, цільові програми, проводять навчання, консультації, інформаційні кампанії. Надалі громади починають доповнювати цю взаємодію іншими формами. Таким чином, співпраця наповнюється новим змістом та охоплює ширше коло суб'єктів. Акцент лише на одній формі залучення громадян не призводить до налагодження системної взаємодії та участі мешканців. Оптимальною є модель, за якої громадяни залучаються як до розробки проектів рішень, так і до їх ухвалення та впровадження. Однак активність мешканців у громадах $\epsilon$ низькою, а місцеві ради недостатньо обізнані щодо всіх механізмів демократії участі. Тому практика налагодження діалогу, розпочинаючи 3 однієї з форм участі, може стати цілком успішною та виправданою. Але в подальшому доцільно шукати нові інструменти та формати взаємодії.

Українська держава перебуває на етапі переходу від моделі представницької демократії до демократії участі, яка, своєю чергою, передбачає активну участь громадськості в управлінні державними справами, а отже й у процесі ухвалення рішень. Головними умовами такої участі $\epsilon$ наявність відповідних правових механізмів та процедур, а також поінформованість широких верств населення щодо можливості такої участі та наявності в членів територіальних громад певних знань та навичок щодо проведення аналізу діяльності органів влади та підготовки пропозицій для подальшого їх врахування владою [1, с. 4].

Місцевий референдум - це спосіб прийняття громадянами нормативно-правових актів та інших суспільно важливих рішень місцевого значення шляхом голосування. На жаль, з листопада 2012 року, зі скасуванням закону України «Про всеукраїнський та місцеві референдуми», такий демократичний інститут як місцевий референдум в Україні 
було знищено. 3 того часу в Україні не проведено жодного місцевого референдуму.

Громадська експертиза діяльності органів виконавчої влади - оцінка діяльності органів виконавчої влади, а також ефективності прийняття та виконання ними рішень 3 метою підготовки пропозицій щодо розв'язання суспільно значущих проблем. На жаль, законодавство не передбачає обов'язковості врахування результатів громадської експертизи безпосередньо при прийнятті владних рішень. Тобто навіть якщо пропозиції будуть розглянуті на засідання органу виконавчої влади, немає гарантії, що вони вплинуть на конкретне вирішення того чи іншого питання.

Консультації з громадськістю - це організоване органами виконавчої влади обговорення 3 громадою питань формування та реалізації державної політики з метою залучення громадян до участі в управлінні місцевими справами, надання можливості для їх вільного доступу до інформації про діяльність органів влади, а також забезпечення гласності, відкритості та прозорості діяльності відповідних органів (конференції, форуми, громадські слухання, круглі столи, збори, зустрічі з громадськістю, теле та радіодебати, Інтернет-конференції, електронні консультації шляхом проведення соціологічних досліджень і спостережень, створення телефонних «Гарячих ліній, тощо).

Громадська рада - постійно діючий колегіальний виборний консультативно-дорадчий орган, утворений для забезпечення участі громадян в управлінні державними справами, здійснення громадського контролю за діяльністю органів влади, врахування позицій громадськості при формуванні та реалізації державної політики.

Загальні збори громадян - це зібрання усіх чи частини мешканців села (сіл), селища, міста для розв'язання питань місцевого значення; вони є формою безпосередньої участі громадян у розв'язанні питань місцевого значення. Рішення зборів, прийняті в межах чинного законодавства, є обов'язковими для виконання органами територіальної самоорганізації громадян, усіма громадянами, які проживають на відповідній території, та мають враховуватись органами місцевого самоврядування. Але, на жаль, на практиці, рішення загальних зборів часто не враховуються місцевими органами влади. Хоча влада i зобов'язана такі рішення розглянути, але не зобов'язана приймати власне рішення у відповідності до рішення загальних зборів.

Територіальна самоорганізація населення - це реалізоване громадою у встановлених законом формах право самостійного та під власну відповідальність здійснення своїх інтересів у питаннях місцевого значення безпосередньо або через створювані органи територіального 
самоуправління. Органи самоорганізації населення $(\mathrm{OCH})$ - це представницькі органи, що створюються мешканцями, які на законних підставах проживають на території села, селища, міста або їх частин, для вирішення завдань, передбачених законодавством [4, с. 24].

Так, різні форми громадської участі в об'єднаних територіальних громадах впливають на ряд процесів місцевого розвитку: розробку стратегії та програм соціально-економічного розвитку, місцевий бюджет, проведення робіт з благоустрою, публічні обговорення, навчаннях тощо. Однак без сприяння ініціативам мешканців громадська активність може піти на спад. Громади проходять складний шлях свого становлення. Бути економічно, фінансово, кадрово спроможними, відновити інфраструктуру, реформувати освітню та медичну галузі - це далеко не весь перелік викликів, які стоять сьогодні перед об'єднаними громадами. I вирішити ці важливі питання дуже складно без діалогу з населенням, без пояснення людям того, куди прямує громада та які перспективи вона отримає в результаті реформи. А залучення населення до процесу розвитку громади дозволить зняти конфліктність та створити спільноту, об’єднану спільними інтересами та цілями.

\section{Література:}

1. Дорох В.В., Черній О.В. Форми участі громадськості в процесах прийняття рішень: Навч.- метод. посіб. - Вінниця: ТОВ «ТВОРИ», 2018. - 104 c.

2. Калашнікова О. Діалог та чіткі правила гри: як ефективно управляти великими ОТГ/ ВГО «Асоціація сприяння самоорганізації населення»/ проект «Відкрита громада - сильна громада»: Українська правда. Київ, 2015.

3. Практичний посібник 3 питань формування спроможних територіальних громад / за заг. ред. : С. М. Серьогіна. - Дніпро : ДРІДУ НАДУ, 2018. - 164 с.

4. Участь громадськості у процесі прийняття рішень на місцевому рівні : посіб. - К. : Ленвіт, 2012. - 64 с. 